\title{
THE CONCEPT OF MASLAHAH ACCORDING TO IMAM AL-GHAZALI
}

\author{
Tarmizi \\ Institut Agama Islam As'adiyah Sengkang \\ Email : tarmizi tahir@yahoo.com
}

\begin{abstract}
Maslahah is the study of the aims and the objectives of Islamic Law. Maslahah is often used by Ulama as a method in resting the law to answer the legal problems that arise. Al-Ghazali mentioned various types of Maslahah viewed from whether it is acknowledged or not by the Shari'ah, which is divided into three types: Maslahah that is acknowledged by the Shari'ah, Maslahah that is rejected by the Shariah, and Maslahah that is neither acknowledged nor rejected by the Shari'ah. Studying the term Maslahah that is associated with the development of modern society is of utmost importance. Maslahah can act as the necessary foundation for the realization of all human interests, both general and specific. So the spirit of Islam, "shalih li kulli zamanin wa makanin" can be realized.
\end{abstract}

\section{Keyword: Maslahat, Interest,AI-Ghazali}

\section{INTRODUCTION}

Islamic law has the spirit that aims to maintain the human interest in this world and the hereafter. Therefore, Islamic law becomes the law that is following the human condition at all times. Maslahah in this world makes it easy for humans to live, while Maslahah in the hereafter guarantees human safety. Islamic law seeks to bring Maslahah to all aspects of human life.

Maslahah is the study of the aims and objectives of Islamic law. Maslahah is often used by Ulemaas a method in resting the law to answer the legal problems that arise. Every human interest, with regards to Maslahah, can be fulfilled both general and specific interests, although some classical and contemporary scholars do not pay much attention and tolerate specificinterest.

Al-Ghazali was a Muslim thinker who lived in the latter part of the Islamic Golden Age under the Abbasid Caliphate, centered in Baghdad. His full name is Abu Hamid Muhammad ibn Ahmad al-Ghazali al-Tusi. Al-Ghazali was born in $450 \mathrm{AH} /$ 1058 AD in Tabaran, a neighborhood in Tus, the second-largest city in Khurasan after 
Nishapur. It is to the name of his hometown that the name al-Ghazali is attributed (alTusi). Al-Ghazali participated in religious-political life in the final years of the Nizam government and later became the central figure of it. He died in his hometown in 505 $\mathrm{H} / 1111$ AD. ${ }^{1}$

The Islamic world gave him the honorary title of Hujjah al-Islam (Defender of Islam) because of his perseverance and services in defending Islam from the onslaught of thoughts that was feared could threaten the existence of Islam, both from philosophers, mutakallimin, batiniyah, and sufis. Likewise, for his efforts to revive Islamic scientific traditions as seen in his monumental masterpiece Ihya Ulum al-Din. ${ }^{2}$

Therefore, studying Maslahahfrom the perspective of al-Ghazali is very important. Moreover, Imam al-Ghazali is a classical religious figure who has a distinct perspective on Maslahah. Maslahah, according to al-Ghazali, can be connected with the views of modern scholars on Maslahah.

\section{DISCUSSION}

\section{A. Biography of al-Ghazali}

Al-Ghazali was a Muslim thinker who lived in the latter part of the Islamic Golden Age under the Abbasid Caliphate, centered in Baghdad. His full name is Abu Hamid Muhammad ibn Ahmad al-Ghazali al-Tusi. Al-Ghazali was born in $450 \mathrm{AH} /$ 1058 AD in Tabaran, a neighborhood in Tus, the second-largest city in Khorasan after Nishapur. It is to the name of his hometown that the name al-Ghazali is attributed (alTusi). Al-Ghazali participated in religious-political life in the final years of the Nizam government and later became the central figure of it. He died in his hometown in 505 $\mathrm{H} / 1111 \mathrm{AD}^{3}$

The Islamic world gave him the honorary title of Hujjah al-Islam (Defender of Islam) because of his perseverance and services in defending Islam from the

${ }^{1}$ Saeful Saleh Anwar, Filsafat IImu Al-Ghazali: Dimensi Ontologi dan Aksiologi, Bandung : Pustaka Setia, 2007, p. 14

${ }^{2}$ Saeful Saleh Anwar, Filsafat Ilmu Al-Ghazali: Dimensi Ontologi dan Aksiologi, p. 15

${ }^{3}$ SaefulSaleh Anwar, Filsafat IImu Al-Ghazali: Dimensi Ontologi dan Aksiologi, Bandung : Pustaka Setia, 2007, p. 14 
onslaught of thoughts that was feared could threaten the existence of Islam, both from philosophers, mutakallimin, batiniyah, and sufis. Likewise, for his efforts to revive Islamic scientific traditions as seen in his monumental masterpiece Ihya Ulum al-Din. ${ }^{4}$

Al-Ghazali was a polymath. His works showed his expertise in ushul al-din (kalam), ushulfigh, fiqh, mantiq (logic), hikmah, philosophy, and tasawuf. In terms of intellectual genealogy, he has many teachers, including Imam Haramayn (Abu alMa'ali al-Juwaini), who is considered to be the most instrumental in fostering alGhazali to become figh and ushul figh expert. At the end of his teacher's life, alGhazali began to show his existence as a great scholar admired by many and began to teach and write. ${ }^{5}$

\section{B. Maslahah according to al-Ghazali}

According to al-Ghazali, Maslahah isthe preservation of the aims of Shari'ah.The aims of the Shari'ahconsist of 1) protection of the religion (hifzhal-din); 2) protection of the life (hifzhal-nafs); 3) protection of the reason (hifzhal-aql); 4) protection of the lineage (hifzh al-nas); and 5) protection of the property (hifzhalmal). ${ }^{6}$

Whereas al-Ghazali mentioned various types of Maslahah viewed from whether it is acknowledged or not by the Shari'ah, which is divided into three types:

1. Maslahah that is acknowledged by the Shari'ah. The Maslahah can be enacted as law and can be deducted to qiyas, by taking the law from the Holy texts and ijma'. Example: the prohibition of consuming intoxicating foods and beverages which qiyas is khamr.

2. Maslahah that is rejected by the Shari'ah.Example: The opinion of some scholars regarding a king who conducts a marital relations during the day in the month of Ramadan, the King should fast for two months in a row. When the opinion was refuted. The scholar then said, if the king was

${ }^{4}$ Sulaiman Dunya, Al-Haqiqah fi Nazr Al-Ghazali, (Mesir: daar al-Ma'arif, tt.,), p. 17

${ }^{5}$ Hasan Ibrahim, Tarikh al-Islam, Juz 4, (Kairo: Maktabah al-Nahdah al-Misriyyah, 1967), p. 236

${ }^{6}$ Al-Ghazali, Al-Mushtasyfa, Juz I, (Beirut:Daar al-Ihya al-Turas al-'Araby, 1997), p. 217 
ordered to free slaves, then it was very easy for him, and he would lightly free slaves to meet his lust. Therefore, the Maslahah is, he must fast for two months in a row, as a deterrent effect. This opinion is invalid and it violates the text with Maslahah. Through this, it is possible to change the provisions and the texts of Islamic law due to changes in conditions and situations.

3. Maslahah that is neither acknowledged nor rejected by the Shari'ah. ${ }^{7}$

The three things mentioned above were used as a basis by al-Ghazali in establishing operational constraints of Maslahah Mursalah, so it can be accepted as the basis for establishing Islamic law:

1. Maslahah must be under the aims of establishing Islamic law, namely, protecting religion, life, reason, lineage, and property.

2. Maslahah must not conflict with al-Qur'an, as-Sunnah, and ljma'.

3. Maslahahmust be atthe daruriyah (primary) or hajiyah (secondary) level, which is equal to daruriyah.

4. Maslahah must be qath'i or zhanni that is close to qath'i.

5. In some cases, conditions are needed; must be qat'iyah, daruriyah, and kulliyah. $^{8}$

Al-Ghazali gives the following conclusions about Maslahah in al-Mustasfa

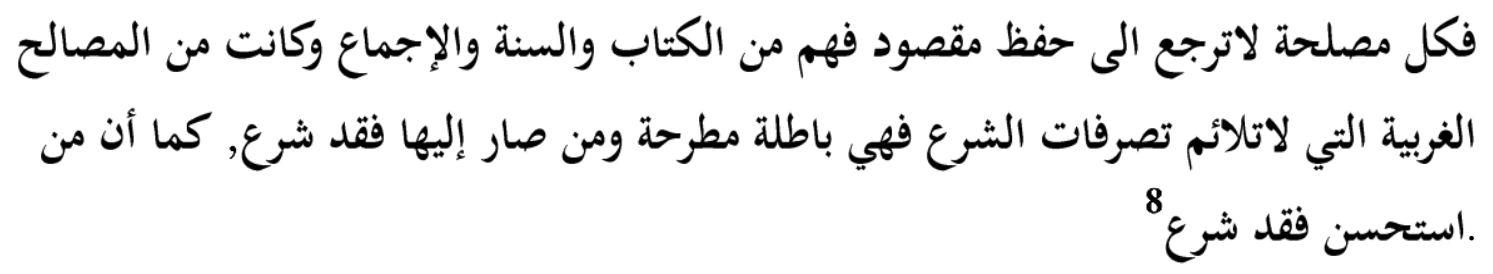

Any Maslahah that does not return to protect the objectives ofthe Islamic law that can be understood from al-Kitab, as-Sunnah, and ljma 'and is the Maslahah of garibah (is foreign) which is not under the act of Shari'ah then the Maslahah is rejected and must be discarded. Whoever is guided by it, he has established Islamic law based on his

${ }^{7}$ Muhammad Al-Ghazali, Al-Mustasfa min IIm al-Ushul, Tahqiq Muhammad Sulaiman alAsyqar, (Beirut: Al-Risalah, 1997), p.414-416

${ }^{8}$ Muhammad Khalid Mas'ud, Islamic Legal Philosoply: A Study of Abu Ishaq al-Shatibi's Life and Thought (Islamabad Pakistan: Islamic Research Istitute, 1977), p. 149-150. 
desires.Similar to people who established Islamic law based on istihsan, he has established Islamic law based on his desires. ${ }^{9}$

From what has been described in the previous section, it appears that alGhazali saw istishlah, not as an independent proposition. He stated:

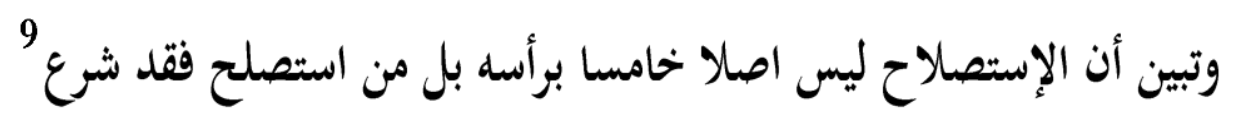

It is clear that istishlah is not the fifth proposition that stands independently. Whoever makes istishlah as an argument (which stands independently), it means he has made up Islamic law based on his desire. ${ }^{10}$

Because of this statement, some scholars of ushul figh assumed that alGhazali rejects Maslahah Mursalah as a method of istinbath. Others consider that alGhazali accepts the istinbath method only if daruriyah, qat'iyah, and kulliyah.

Based on the operational conditions made by al-Ghazali, it appears that alGhazali did not view Maslahah Mursalah as an independent proposition, apart from alQur'an, as-Sunnah and ijma'. Al-Ghazali viewed the problem of mursalah only as a method of istinbath (inquiry), not as an argument or source of Islamic law.

While the operational scope of the Maslahah Mursalah was not explicitly mentioned by al-Ghazali, but based on the research of Ahmad Munif Suratma Putra on the cases of Maslahah Mursalah raised by al-Ghazali in his books (al-Mankul, Asas alQiyas, Shifa al-Galil, al-Mustasfa), it can be concluded that al-Ghazali limits the scope of Maslahah Mursalah only in Mu'amalah. ${ }^{11}$

Maslahah is justified by al-Ghazali, for example, if the property has been mixed with property gained by corruption, collusion, manipulation, or looting,and it is difficult to get a purely halal property. Then based on Maslahah, it is permissible or lawful to buy a property based on their needs through halal transactions. If it is not justified, then the economic system and religious activities will be stopped, and it will bring negative impacts on people's lives. Such conditions are not justified by Islam.

${ }^{9} \mathrm{Al}-$ Ghazali, Al-Mushtasyfa, Juz I, p. 430.

${ }^{10} \mathrm{Al}-$ Ghazali, Al-Mushtasyfa, Juz l, p. 311.

${ }^{11}$ Ahmad Munif Suratmaputra, Filsafat Hukum Islam al-Ghazali: Maslahah Mursalah dan Relevansinya dengan Pembaharuan Hukum Islam, p. 144 
This attitude is prioritizing mafsadat prevention and creating Maslahah for the more significant benefit of humanity.

Thus, it is evident that great scholars, both from Maliki and Shafi'l madhhabs, accept Maslahah Mursalah as the basis for establishing Islamic law with the following conditions: First, the law must contain Maslahah. Secondly, the Maslahah is under the objectives of the establishment of Islamic law, namely protecting the religion, life, the reason, the lineage, and the property. Third, Maslahah that fulfills the criteria mentioned in the second point is not shown by specific laws that justify or reject it. The scope of implementation is limited tothe fields mu'amalah and traditions, and not implemented in the field of worship.

The scholars used different terms for the implementation of Maslahah Mursalah, even al-Ghazali used several terms to refer to it, so it had implications in the understanding of the succeeding scholars regarding the opinion of the previous scholars on this issue. In al-Mankul, al-Ghazali mentioned Maslahah Mursalah with the term istidlal sahih (not istidlal mursal), in Asas al-Qiyas, he used the term istislah, and in Shifa al-Galil he calleditmunasibmula'im, whereas in al-Mustasfa, al-Ghazali called it Maslahah Mursalah. Since al-Ghazali mentioned Maslahah Mursalah with several terms, there is an opinion that argued that al-Ghazali is inconsistent in making Maslahah Mursalah as the basis of establishing Islamic law. The use of these different terms also has implications for the distortion of the understanding of the next generation regarding Maslahah Mursalah.

The objective of the law, mainly, is to bring Maslahah and prevent humans from chaos. Thus this view is under the principle of al-muhafazhat 'ala al-Qadim alshalih wal akhdzu bi al-jadidd al-ashlah, which is to be selective and accommodating to changes for the fulfillment of Maslahah that are based on the objectives of theShari'ah. Therefore, one of the principles that need to be considered from al-Ghazali's theory of Maslahah is the priority scale, which prioritizes the protection of mafsadat rather than Maslahah, because preventing mafsadat, in essence, means giving priority to a more significant and most urgent Maslahah than the other Maslahah. This act is under the rules of Dar'u al-mafasid muqaddamun ala jalb al-mashalih. 


\section{CONCLUSION}

The following points can be concluded from this study on Maslahah, according to al-Ghazali: First, Al-Ghazali was a Muslim thinker who lived in the latter part of the Islamic Golden Age under the Abbasid Caliphate, centered in Baghdad. His full name is Abu Hamid Muhammad ibn Ahmad al-Ghazali al-Tusi. Al-Ghazali was born in $450 \mathrm{AH} / 1058 \mathrm{AD}$ in Tabaran, a neighborhood in Tus, the second-largest city in Khurasan after Nishapur. It is to the name of his hometown that the name alGhazali is attributed (al-Tusi).

Second, according to his theory, the aim of Maslahah to protect the objectives of the Shari'ah, which are consisted of: 1) protection of the religion (hifzhaldin); 2) protection of the life (hifzhal-nafs); 3) protection of the reason (hifzhal-aql); 4) protection of the lineage (hifzh al-nasl); and 5) protection of the property (hifzhal-mal).

Studying the term Maslahah that is associated with the development of modern society is of utmost importance. Maslahah can act as the essential foundation for the realization of all human interests, both general and specific. So the spirit of Islam, shalih li kulli zamanin wa makanin can be realized.

\section{REFERENCES}

Anwar, Saeful Saleh. Filsafat IImu Al-Ghazali: Dimensi Ontologi dan Aksiologi. Bandung : Pustaka Setia, 2007.

Awadah, Muhammad. Malik bin Anas Imam Dar al-Hijarah. Beirut: Dar al-Kutub alIlmiyah, 1992.

Bandari, Abdul Ghafur Sulaiman, al-Mausu'ahRijal al-Kutub al-Tis'ah. juz III. Beirut: Dar al-Kutub al-Islamiyah, 1993.

Gazali, Muhammad al-.Al-Mustasfa min IIm Ushul. Tahqiq Muhammad Sulaiman alAsyqar, Beerut/Libanon: Al-Risalah, 1997 M./1418 H.

Ghougassian, Joseph peter. Sayap-sayap Pemikiran Khalil Gibran. Yogyakarta.Fajar Pustaka Baru. 2002.

Hallag, Wael B. A History of Islamic Legal Theories, diterjemahkan E. Kusnadiningrat. Jakarta: Rajawali Press, 2000.

Ismail, M. Syuhudi. Hadits Nabi yang Tekstual dan Kontekstual, Telaah Ma 'ani alHadits tentang Ajaran Islam yang Universal, Temporal, Lokal. Cet.I; Jakarta: Bulan Bintang,1994. 
Kamali, Abdullah, al-.Maqashid al-Syari'ah fi Dau' Fiqhal-Muuwazanat. Cet.l;BeirutLibanon: Dar al-Fikr,2000.

Khallaf, Abdul Wahab. Sejarah Pembentukan dan Perkembangan Hukum Islam. Jakarta: Rajawali Press,2003.

Mas'ud, Muhammad Khalid. Islamic Legal Philosoply: A Study of Abu Ishaq alShatibi's Life and Thought. Islamabad Pakistan: Islamic Research Istitute, 1977.

Meuleman, Hendrik. Tradial Kemodernan dan Metamodernisme: Memperbin-cangkan pemikiran Muhammad Arkoun. Yogyakarta: LKIS, 1996.

Mua'llim, Amir danYusdani. Konfigurasi PemikiranHukum Islam. Cet. I; Yogyakarta: UII Press, 1999.

Rahman, Fazlur. Membuka Pintu ljtihad. Cet. I; Bandung: Pustaka, 1995.

Supriyadi, Dedi. Perbandingan Madzhab Dengan Pendekatan Baru. Bandung: PustakaSetia, 2008.

Suratmaputra, Ahmad Munif .Filsafat Hukum Islam Al-Ghazali: Mashlahah Mursalah \& Relevansinya dengan Pembaharuan Hukum Islam. Jakarta: Pustaka Firdaus, 2002.

Syatibi, Abu Ishak al-.Al-I'tisham.Jilid II. Baerut: Dar al-Ma'rifah, 1975. 